\title{
Advancing biometeorological insights: a third special issue from the students and new professionals of the ISB
}

\author{
Jennifer K. Vanos ${ }^{1}(\mathbb{D})$ Angela M. Lees ${ }^{2}(\mathbb{0}$
}

Received: 9 December 2021 / Revised: 9 December 2021 / Accepted: 10 December 2021 / Published online: 14 January 2022

(C) The Author(s) under exclusive licence to International Society of Biometeorology 2021

We are pleased to present the third Special Issue (SI) published in the International Journal of Biometeorology dedicated to highlighting research conducted by members of the Students and New Professionals (SNP) within the International Society of Biometeorology (ISB). The current SI arose from discussions first presented at the International Congress of Biometeorology in Durham (2017) and the 3rd International SNP workshop held at the University of Twente (2019). The SI presented here follows the success of two previous SIs by the SNP, published in 2014 (Gosling 2014), following our 19th ICB in Auckland, NZ, and a second issue published in 2017, following our 20th ICB in Cleveland, Ohio (Gosling 2018). Both issues were organized and edited by Dr. Simon Gosling of the University of Nottingham. Combined these two SIs published 30 articles, and to date, have attracted an impressive 700 citations as of December 2021 (according to Springer).

Importantly, these two previous SIs have acted as a springboard for numerous collaborative research activities within the SNP, including Biometeorological Education (Allen et al. 2017; Perkins et al. 2017) and Biometeorological Technology (Anderson et al. 2021), as well as the first Biometeorological Glossary originating from 14 members in the SNP in 2014 (Gosling et al. 2014).

On the back of successful first and second SIs, we are pleased to present the third Special Issue by the SNP, where 15 articles are advancing the way in which we think about, approach, and study Biometeorology across multiple domains. Importantly, these articles provide research findings from eight countries and diverse climate zones. Within

Angela M. Lees

angela.lees@une.edu.au

1 School of Sustainability, College of Global Futures, Arizona State University, Tempe, AZ, USA

2 School of Environmental and Rural Science, University of New England, Armidale, NSW, Australia this issue, two predominant themes are presented: (1) urban heat variability and thermal comfort and (2) the impacts of weather on animals.

The scientific community has been studying the effects of weather on animals for decades. What remains well-documented is that climatic conditions profoundly impact animal production, health, and well-being. For example, within this issue, Wallage et al. (2021) investigate the impact of simulated acute and chronic exposure to heat stress on bull's capacity to regulate scrotal temperature. The authors have described that the thermoregulatory mechanisms responsible for maintaining bovine scrotal temperature fail during whole-body exposure to heat stress. Following this, Steel et al. (2021) evaluate the relationship between climatic conditions up to 28 days prior to feedlot exit on the incidence of dark cutting in grain-fed beef, finding that the climatic conditions in this period have a small but inherent role in dark cutting. Lees et al. (2021a) study the benefits of feeding live yeasts on reducing the impact of heat stress on lactating dairy cows, finding that the supplementation may support thermoregulation via decreased body temperature and improved respiratory dynamics. Related, Lees et al. (2021c) evaluate the effectiveness of the Dairy Heat Load Index (DHLI) to predict heat load responses of lactating dairy cows, concluding that the DHLI was a good predictor of body temperature and changes in milk yield. Finally, at the nexus between human health and animals, Fitchett and Swatton (2020) investigate malaria awareness and proactive responses in South Africa. The authors found that survey respondents appeared to have a high awareness of malaria, although overestimated the spatial distribution of risk, yet they did not utilize precautionary measures when visiting malaria-prone regions.

Shifting to thermal comfort and heat, Banerjee et al. (2021) assess predicted and actual outdoor thermal comfort in tropical Mumbai, India, in entrepreneurial settings with limited cooling available. Findings demonstrate the 
importance of heat acclimatization for thermal comfort with large differences in neutral physiological equivalent temperature in summer and winter dependent on location. Thermal perception connected to self-reported health effects was studied by Adegebo (2021) in Ibadan, southwest Nigeria, highlighting variability in personal perceptions of warm weather and important connections to heat illness indicators. Similarly, work herein by Dzyuban et al. (2021) also assesses thermal perception, yet in the hot and dry climate of Phoenix, Arizona, USA, and associates these responses with public transit infrastructure (e.g., shade, vegetation). Shade and climate type also played a crucial role in results from Vanos et al. (2021), whereby evaporative misters plus shade was the most impactful solution for outdoor thermal comfort in the hot, dry climate of Tempe, AZ, USA, with thermal comfort an important motivation of business mister use.

Analyzing the impacts of urban design and season on air temperature dynamics within cities were important goals of Milošević et al. (2021) and Kabano et al. (2021), respectively. Milošević et al. (2021) assessed varying cooling rates, heating rates, and urban heat island intensities depending on local climate zones in Novi Sad, Serbia. In Kampala, Uganda, Kabano et al. (2021) found that the advancement of the dry season increased climate variability, with the most built-up locations experiencing the most profound seasonal changes in climate. Nature within cities and its near-surface cooling potential was studied by Anderson and Gough (2021) in Toronto, Canada, showing that urban agriculture supported cooling to the greatest extent by $0.5^{\circ} \mathrm{C}$ air temperature on average.

An assessment of surface wind speed and aircraft operation was completed by Leung et al. (2020) in Hudson Bay and Labrador, Canada (1971-2010). Authors found that important increases in high wind speeds were present that could affect aircraft takeoff and landing due to near-threshold limits reached. The sole review within this issue was offered by Anderson et al. (2021) and covers various technological opportunities that can be used within human, plant, and animal biometeorology into the future. Finally, the SNP Chair, Angela Lees, and colleagues provide an important news updates for the SNP and ISB membership (Lees et al. 2021b).

In summary, this SI presents research by numerous SNP members, representing the diversity of research topics being investigated by the SNP. Furthermore, these publications highlight the high-quality novel research being conducted by SNP members. Moving forward, we will strive to continue the expansion of the SNP network and increase global participation. We are eager to support diversity and inclusion across research and membership within the ISB and have recently helped craft our Society's diversity statement (https://uwm.edu/biometeorology/about/diversity/) put forth by the Executive Board. For the SNP, we will continue supporting upcoming generations of scientists and practitioners to collaborate across disciplines to achieve a more healthy and sustainable future for all. We strongly encourage all interested to become active members within ISB and/or the SNP group (https://uwm.edu/biometeorology/isb-membe rship/). Finally, we look forward to gathering in person in Tempe, AZ, USA, in 2023 for our next Congress (https:// uwm.edu/biometeorology/congress/).

\section{References}

Adegebo BO (2021) Urban thermal perception and self-reported health effects in Ibadan, southwest Nigeria. Int J Biometeorol. https://doi. org/10.1007/s00484-021-02168-z

Allen MJ, Vanos J, Hondula DM et al (2017) Supporting sustainability initiatives through biometeorology education and training. Int J Biometeorol 61:93-106. https://doi.org/10.1007/ s00484-017-1408-Z

Anderson V, Gough WA (2021) Nature-based cooling potential: a multi-type green infrastructure evaluation in Toronto, Ontario, Canada. Int J Biometeorol. https://doi.org/10.1007/ s00484-021-02100-5

Anderson V, Leung ACW, Mehdipoor H et al (2021) Technological opportunities for sensing of the health effects of weather and climate change: a state-of-the-art-review. Int J Biometeorol 65:779803. https://doi.org/10.1007/s00484-020-02063-z

Banerjee S, Middel A, Chattopadhyay S (2021) A regression-based three-phase approach to assess outdoor thermal comfort in informal micro-entrepreneurial settings in tropical Mumbai. Int J Biometeorol. https://doi.org/10.1007/s00484-021-02136-7

Dzyuban Y, Hondula DM, Coseo PJ, Redman CL (2021) Public transit infrastructure and heat perceptions in hot and dry climates. Int $\mathrm{J}$ Biometeorol. https://doi.org/10.1007/s00484-021-02074-4

Fitchett JM, Swatton D-A (2020) Exploring public awareness of the current and future malaria risk zones in South Africa under climate change: a pilot study. Int J Biometeorol. https://doi.org/10. 1007/s00484-020-02042-4

Gosling SN (2014) New insights into biometeorology. Int J Biometeorol 58:101-102. https://doi.org/10.1007/s00484-014-0793-9

Gosling SN (2018) Additional new insights into biometeorology. Int J Biometeorol 62:1-2. https://doi.org/10.1007/s00484-017-1478-y

Gosling SN, Bryce EK, Dixon PG et al (2014) A glossary for biometeorology. Int J Biometeorol 58:277-308. https://doi.org/10.1007/ s00484-013-0729-9

Kabano P, Harris A, Lindley S (2021) Spatiotemporal dynamics of urban climate during the wet-dry season transition in a tropical African city. Int J Biometeorol. https://doi.org/10.1007/ s00484-020-02061-1

Lees AM, Olm JCW, Lees JC, Gaughan JB (2021a) Influence of feeding Saccharomyces cerevisiae on the heat load responses of lactating dairy cows during summer. Int J Biometeorol. https://doi.org/ 10.1007/s00484-021-02169-y

Lees AM, Vecellio DJ, Dzyuban Y (2021b) A news update from the students and new professionals group. Int J Biometeorol. https:// doi.org/10.1007/s00484-021-02203-Z

Lees JC, Lees AM, Gaughan JB (2021c) The influence of shade availability on the effectiveness of the Dairy Heat Load Index (DHLI) to predict lactating cow behavior, physiology, and production traits. Int J Biometeorol. https://doi.org/10.1007/s00484-021-02186-x

Leung ACW, Gough WA, Butler KA et al (2020) Characterizing observed surface wind speed in the Hudson Bay and Labrador 
regions of Canada from an aviation perspective. Int J Biometeorol. https://doi.org/10.1007/s00484-020-02021-9

Milošević D, Savić S, Kresoja M et al (2021) Analysis of air temperature dynamics in the "local climate zones" of Novi Sad (Serbia) based on long-term database from an urban meteorological network. Int J Biometeorol. https://doi.org/10.1007/ s00484-020-02058-w

Perkins DR IV, Vanos J, Fuhrmann C et al (2017) Enhancing the teaching and learning of biometeorology in higher education. Bull Am Meteorol Soc 98:ES239-ES242

Steel C, Lees AM, Tarr G et al (2021) The impact of weather on the incidence of dark cutting in Australian feedlot cattle. Int J Biometeorol. https://doi.org/10.1007/s00484-021-02180-3
Vanos JK, Wright MK, Kaiser A et al (2021) Evaporative misters for urban cooling and comfort: effectiveness and motivations for use. Int J Biometeorol. https://doi.org/10.1007/s00484-020-02056-y

Wallage AL, Lees AM, Lisle AT et al (2021) Thermoregulation of the bovine scrotum 2: simulated acute and chronic heat waves reduces the scrotal thermoregulatory capability of Wagyu bulls. Int J Biometeorol. https://doi.org/10.1007/s00484-021-02108-x

Publisher's note Springer Nature remains neutral with regard to jurisdictional claims in published maps and institutional affiliations. 